\title{
A Phase II Study of Ifosfamide, Carboplatin, and Epirubicin (ICE) Combination Chemotherapy for Extensive Disease of Small Cell Lung Cancer
}

\author{
Jae Ho Byun, M.D., In Sook Woo, M.D., Hun Ho Song, M.D., Keun Seok Lee, M.D., Jin Seok Ahn, M.D., \\ Dae Young Jang, M.D., Jung-Ae Lee, M.D., Young lee Park, M.D. and Young Suk Park, M.D.
}

Division of Hemato-Oncology, Department of Internal Medicine, Hallym University College of Medicine, Chuncheon, Korea

Purpose: To evaluate the efficacy and safety of ifosfamide, carboplatin and epirubicin (ICE) combination chemotherapy for extensive disease small cell lung cancer (SCLC) patients, who had received no previous chemotherapy, we performed phase II trial between August 1998 and January 2001.

Materials and Methods: The study group comprised of 21 patients. Ifosfamide, $1,500 \mathrm{mg} / \mathrm{m}^{2}$, was given with mesna, $900 \mathrm{mg} / \mathrm{m}^{2}$, intravenously for 12 hours on days 1,2 and 3 , and carboplatin, $4.5 \mathrm{mg} / \mathrm{ml} / \mathrm{min}$, for target AUC, and epirubicin, $60 \mathrm{mg} / \mathrm{m}^{2}$, were given intravenously for 90 minutes on day 1 . The cycle of treatment was repeated at 4 week intervals.

Results: Twenty-one patients with extensive disease SCLC were treated at Hallym University between August 1998 and January 2001. One patient was unable to be evaluated because of lost to follow-up. Of the 20 patients able to be evaluated, an objective response was observed in $13(65 \%)$. There were no complete responses. The

\section{서 론}

소세포폐암은 전체 폐암의 $20 \sim 25 \%$ 를 차지하고 있으며 다른 종류의 폐암과는 임상적 특징 및 생물학적 특징이 다 르다. 대부분의 예에서 진단 당시 이미 원격전이가 되어 수 술적 절제에 의해서는 극소수의 환자에서 완치가 가능하 며, 약 2/3의 환자에서 진단 당시에 임상적으로 전이 병소를 찾을 수 있는 전신성 병기(extensive disease)로 최초 진단된 다 $(1,2)$. 비록 소세포폐암이 항암제에 잘 반응하는 종양으로

Correspondence: Young Iee Park, Hangang Sacred Heart Hospital, Division of Hemato-Oncology, Department of Internal Medicine, Hallym University College of Medicine, 94-200, Yeoungdeungpo-dong, Yeoungdeungpo-gu, Seoul 150-037, Korea. Tel: 02-2369-5400, Fax: 02-677-9756, E-mail: youngiee@ dreamwiz.com

Received October 2, 2002, Accepted November 28, 2002 median response duration, time to progression and median overall survival were 15.4, 18.3 and 34 weeks, respectively. Toxicities were acceptable, with dose reduction for myelosuppression necessary in only a minority of the patients. A total of 85 cycles of chemotherapy were given to the patients. The median number of cycles completed was 4 . Grade III and IV hematological toxicities included anemia $(4.7 \%)$, neutropenia $(3.5 \%)$ and thrombocytopenia (3.5\%). Most non-hematological toxicities were grade I or II.

Conclusion: These results suggested that ICE combination chemotherapy for extensive disease SCLC is effective, and can be safely administered with acceptable toxicities. (Cancer Research and Treatment 2002;34:416420)

Key Words: Small cell lung cancer, Chemotherapy, Ifosfamide, Carboplatin, Epirubicin
다양한 종류의 복합항암화학요법이 시행되고 있으나, 제한 성 병기의 경우 완전관해는 $40 \sim 60 \%$ 이고 2 년 생존율은 10 $20 \%$ 이다. 전신성 병기의 경우 완전관해는 더 낮으며, 2 년 생존율도 $5 \%$ 미만으로 $(3,4)$ 장기 생존은 드물다. 소세포폐 암에 대한 약제는 주로 cylophophamide, doxorubicin, cisplatin, carboplatin, etoposide, vincristine, ifosfamide 등이 있으 며 이러한 약제를 이용한 복합항암화학요법이 흔히 사용되 고 있다. 1980년대까지 cyclophosphamide, doxorubicin, vincristine $(\mathrm{CAV})$ 이 주요 복합항암화학요법이었으며 그 후 etoposide, cisplatin (EP)요법의 효과가 입증 받아 널리 사용되 어 왔다(5). 효과적인 약제의 수를 증가시키는 방법, 약제의 용량을 증가시키는 방법, 약제 투여 간격을 줄이는 방법 등 여러 새로운 방법들이 제시되어 반응률은 증가시켰지만 생 존기간의 증가는 거의 없는 실정이다. 이에 저자들은 이전 에 치료받은 적이 없는 전신성 병기의 소세포폐암 환자들 을 대상으로 단일약제로서 효과가 입증된 ifosfamide, car- 
boplatin, epirubicin을 이용한 3제 복합화학요법 (ICE)의 치 료효과와 안전성을 평가하고자 하였다.

\section{대상 및 방법}

1998년 8월부터 2001년 5월까지 한림대학교 의료원에서 전신성병기의 소세포폐암으로 확진된 21 명의 환자를 대상 으로 하였다.

\section{1) 대상환자의 선정기준}

병리조직학적으로 소세포폐암으로 확진이 되고, 화학요 법이나 방사선요법을 받은 과거력이 없으며, 환자의 활동 도는 ECOG 기준 0-3으로, 적절한 골수, 간 및 신기능을 가 진 환자로 $\left(\mathrm{WBC} \geq 4,000 / \mathrm{mm}^{3}\right.$, platelet $\geq 100,000 / \mathrm{mm}^{3}$, bilirubin $<2.0 \mathrm{mg} / \mathrm{dl}, \mathrm{AST} / \mathrm{ALT}<2 \times$ normal, creatinine $\leq 1.5 \mathrm{mg} / \mathrm{dl}$ ), 치료에 영향을 줄 수 있는 다른 심각한 질환을 않고 있지 않는 경우로 하였다. 전신성 병기의 정의는 제한성 병기 이 상의 질환 상태로 하였고 제한성 병기로는 원발 병소가 한 쪽 흉곽에만 국한되어 있고, 림프절의 전이는 일측 쇄골 상 부 림프절, 양측 종격동 림프절, 동측 폐문부 림프절까지 침 윤된 경우로 하였고, 동측 흉막 삼출액이 있는 경우도 제한 성 병기로 포함하였다. 다른 종류의 암의 기왕력이 있거나 현재 있는 환자(단 치료된 비흑색종 피부암 또는 경부암은 해당되지 않음), 중추신경계에 전이가 된 환자, 환자의 동의 서를 이해하는 데 있어 장애가 될 정도의 정신 신경적으로 비정상이거나 치매인 환자는 제외하였다. 본 연구는 본원 의 임상시험 심의 위원회의 승인을 얻어 시행하였고, 모든 환자에게서 서면 동의서를 받았다.

\section{2) 병기 결정을 위한 검사}

치료 시작 전에 모든 환자에 대하여 병력청취 및 신체검 사, 흉부 X-선 검사, 일반혈액검사. 일반화학검사, 흥부 전 산화 단층촬영(간 및 부신까지 포함), 골주사, 골수 흡인 및 생검을 시행하였다.

\section{3) 치료 방법}

복합항암화학요법은 제 1 일부터 3 일간 ifosfamide를 $1,500 \mathrm{mg} / \mathrm{m}^{2}$ 을 mesna $900 \mathrm{mg} / \mathrm{m}^{2}$ 과 함께 12 시간 지속 정주 하였고, carboplatin은 제 1일에 AUC $4.5 \mathrm{mg} / \mathrm{ml} \cdot \min$ 를 목표 로 Calvert formula를 통해서 계산된 용량을 1 시간 정주하였 으며, epirubicin은 제 1 일에 $60 \mathrm{mg} / \mathrm{m}^{2}$ 을 90 분 동안 정주하는 것을 매 4주마다 반복하였다. 치료는 진행성 병변을 보이는 경우나 투여를 중지해야 할 정도의 독성이 나타날 때까지 치료를 지속하였고, 명확한 진행성 병변의 소견이 없는 불
변의 경우 최소 6 주기를 투여하고 연구자의 판단에 따라 최대 8주기까지 투여하였다. 환자가 중증의 독성을 나타내 어 투약이 어려운 경우, 진행성 병변을 보이는 경우, 환자가 원하는 경우 또는 기타 연구자의 판단에 따라 필요한 경우 투약을 종료하였다. 다음주기의 투여는 매 4주마다 반복하 는 것을 원칙으로 하였고, 매회 항암제를 투여하기 전에 일 반 혈액검사 및 일반 화학검사를 시행하여 항암제 투여를 결정하였다. 즉 다음 주기의 치료 개시 전 검사한 일반 혈액 검사 결과가 절대호중구수 $>1.5 \times 10^{9} / \mathrm{L}$, 혈소판수 $>100 \times$ $10^{9} / \mathrm{L}$ 이상이고 일반 화학검사에서 이상이 없는 경우에 투 여를 시작하였고, 28 일에 혈액학적 독성으로부터 회복되지 않은 경우, 매주 혈액검사를 시행하여 42 일 내 절대호중구 수 $>1.5 \times 10^{9} / \mathrm{L}$, 혈소판수 $>100 \times 10^{9} / \mathrm{L}$ 이상이 되면 다음주 기를 투여하였다.

\section{4) 치료효과의 판정기준}

치료효과에 대한 평가를 위해 매 치료 직전에 신체검사, 흥부 X-선 촬영을 시행하였고, 매 3주기마다 흥부 전산화단 층촬영, 골 주사를 시행하였다. 치료효과에 대한 판정은 $\mathrm{WHO}$ 기준에 따라 임상적으로 계측 가능한 병변이 완전히 소실되고 이것이 4주 이상 지속된 경우 완전관해, 새로운 병변의 발생 없이 $50 \%$ 이상의 종괴 소실을 보인 경우는 부 분관해로 하였고, $50 \%$ 미만의 종괴 소실을 보이거나 병소 의 크기가 $25 \%$ 미만 증가된 경우는 안정반응, 그리고 치료 에도 불구하고 병소의 크기가 $25 \%$ 이상 증가되거나 새로운 병변이 발생하는 경우 진행으로 판정하였다. 치료에 의한 독성의 판정은 $\mathrm{NCI}$ 기준으로 하였다.

\section{5) 통계분석방법}

관해유지 기간은 임상적으로 관해로 진단된 날부터 진행 이 확인된 날까지로 하였고, 생존기간은 치료 시작일부터 사망일까지 또는 마지막 추적 관찰일까지로 하였다. 병변 의 진행까지의 기간은 치료 시작일부터 병변이 진행될 때 까지로 하였다. 관해 유지기간 및 생존기간, 병변의 진행까 지의 기간의 중앙치는 Kaplan-Meier법에 의해 구하였다.

\section{결 과}

\section{1) 대상환자의 특성 및 치료}

1998년 8월부터 2001년 5월까지 21예가 등록되었다. 대 상 환자의 중앙 연령값은 60세(범위 47 74)였고 남녀비는 $17: 4$ 였으며 활동도는 ECOG 기준으로 Grade 0-1이 15명 Grade 2 3이 6명이였다. 총 85주기의 약물투여를 시행하였 으며, 치료주기의 중앙값은 4 주기(2 8주기)였다(Table 1). 


\section{2) 관해율과 관해유지기간}

등록된 환자 중 1 명은 1 회 항암화학요법 시행 후 추적 관 찰이 되지 않아 제외하고 20 명의 환자에 대하여 분석하였 다. 치료 반응률은 65\% (13/20)였다. 완전관해는 없었고 모 두 부분 관해였다(Table 2). 반응을 보인 13명의 관해 유지 기간의 중앙값은 15.4 주(범위 $4.3 \sim 47.9$ 주)였다.

\section{3) 생존기간}

전체 환자의 추적 관찰기간은 중앙값 34 주이었고, 생존 기간은 중앙값 34 주(범위 $8.7 \sim 62.7$ 주), 질병의 진행까지의 기간은 중앙값이 18.3 주(범위 6.3 54.4주)였다(Fig. 1, 2).

\section{4) 부작용}

평가 가능한 20 명의 환자에서 총 85 주기가 투여되었다. 혈액학적 독성으로 NCI 기준 3도/4도의 빈혈이 4회(4.7\%), 3 도 4 도의 백혈구 감소증은 3회(3.5\%), 혈소판 감소증은 3회 $(3.5 \%)$ 로 나타났으며 백혈구 감소증에 의한 감염이 1 회 있 었으나 치료에 따른 사망은 없었다. 비혈액학적 독성으로 오심 구토 구내염 등이 있었으나 2도 이하였다(Table 3).

\section{5) 용량강도}

계획된 ifosfamide와 epirubicin의 용량은 각각 $375 \mathrm{mg} / \mathrm{m}^{2} /$

Table 1. Patient characteristics

\begin{tabular}{llr}
\hline Number of patients & & 21 \\
\hline Sex (male/female) & Male/Female & $17 / 4$ \\
Median age, years (range) & $60(47 \sim 74)$ & \\
Performance status & ECOG: $0 \sim 1$ & 15 \\
& ECOG: $2 \sim 3$ & 6 \\
Chemotherapy & & \\
$\quad$ Total number of cycle & 85 & \\
$\quad$ Median cycle & $4(2 \sim 8)$ & \\
\hline
\end{tabular}

Table 2. Objective response

\begin{tabular}{lc}
\hline Response & No (\%) \\
\hline $\mathrm{CR}^{*}$ & 0 \\
$\mathrm{PR}^{\dagger}$ & $13(65.0 \%)$ \\
$\mathrm{SD}^{\ddagger}$ & $3(15.0 \%)$ \\
$\mathrm{PD}^{\S}$ & $4(20.0 \%)$ \\
\hline
\end{tabular}

${ }^{*}$ : complete remission, ${ }^{\dagger}$ : partial remission, ${ }^{\ddagger}$ : stable disease, ${ }^{\S}$ : progressive disease week, $15 \mathrm{mg} / \mathrm{m}^{2} /$ week이었다. 실제 환자에게 투여된 용량강 도의 중앙값은 ifosfamide가 $313.6 \mathrm{mg} / \mathrm{m}^{2} /$ week (범위 216.5 $470.4 \mathrm{mg} / \mathrm{m}^{2} /$ week)이었고 epirubicin은 $12.5 \mathrm{mg} / \mathrm{m}^{2} /$ week (범

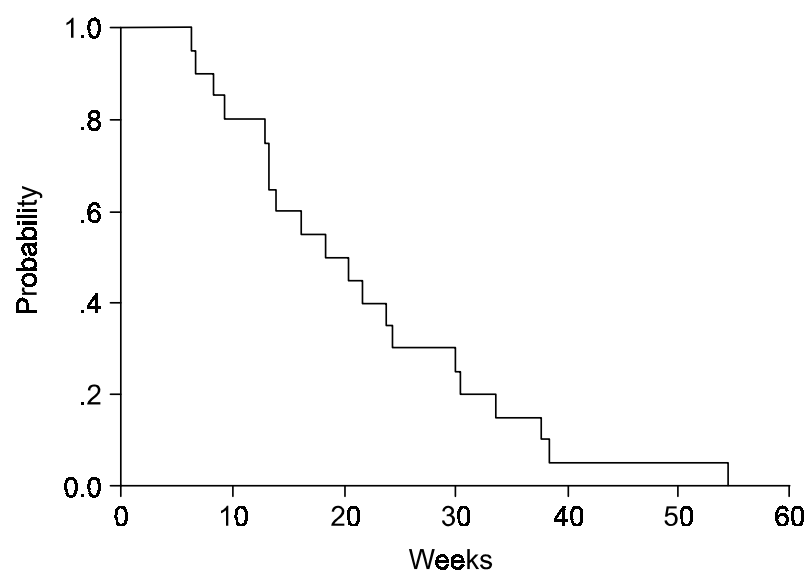

Fig. 1. Curve of time to progression

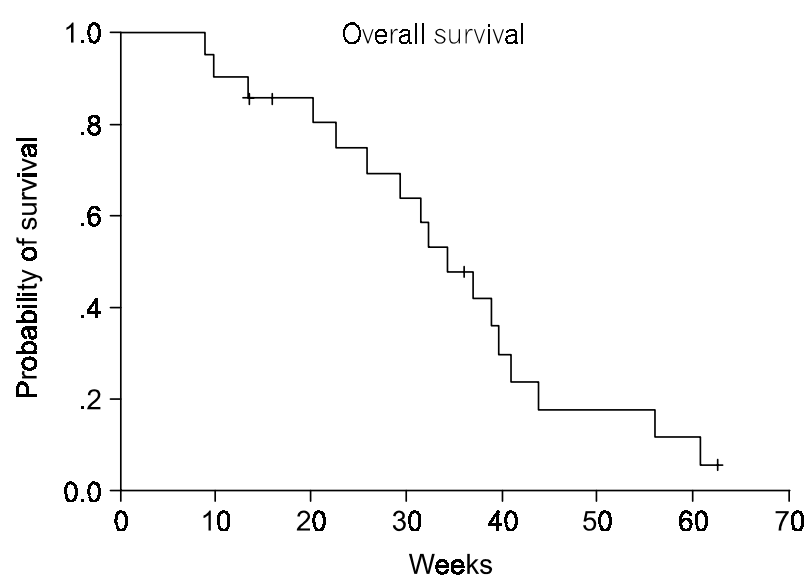

Fig. 2. Overall survival

Table 3. Toxicity

\begin{tabular}{llccc}
\hline & & Grade I/II & Grade III & Grade IV \\
\hline Hematologic & Leukopenia & 8 & 0 & 3 \\
& Thrombocytopenia & 1 & 1 & 2 \\
& Anemia & 28 & 2 & 2 \\
Nonhematologic & Nausea/vomiting & 46 & 0 & 0 \\
& Stomatitis & 12 & 0 & 0 \\
& Hepatotoxicity & 2 & 0 & 0 \\
& Diarrhea & 1 & 0 & 0 \\
& Nephrotoxicity & 3 & & \\
& Neuropathy & 2 & 0 & 0 \\
\hline
\end{tabular}


위 $8.9 \sim 16.1 \mathrm{mg} / \mathrm{m}^{2} / \mathrm{week}$ )이었다. 상대용량강도의 중앙값은 각각 0.84 (95\% CI, $0.65 \sim 1.03), 0.84$ (95\% CI 0.62 1.06)였 다. 반응이 있었던 환자에서 투여된 용량을 살펴보면 투여 예정량이 $70 \%$ 이상 투여되었다.

\section{고 찰}

소세포폐암은 성장속도가 빠르고 조기에 원격전이를 잘 한다. 항암화학요법 및 방사선요법에 비교적 높은 반응률 을 나타내므로 소세포폐암 환자에게 적극적인 치료가 생존 율 향상에 도움이 된다고 알려져 있다(6). 항암화학요법이 시작된 이후 초기에는 완치 가능한 암종으로 생각하였으 나(7) 복합항암화학요법으로도 반응률은 좋으나 생존기간 은 제한성 병기의 경우 중앙 생존기간이 12 20개월이고 전신성 병기의 경우 7 11개월로 만족스럽지 못한 상황이 다. 현재 가장 많이 사용되는 복합항암화학요법으로는 $\mathrm{CAV}$ 와 $\mathrm{EP}$ 이다. $\mathrm{CAV}$ 복합항암화학요법은 전신성 병기의 환자 에서 $50 \sim 90 \%$ 의 관해율과 $10 \sim 20 \%$ 의 완전 관해율을 보이 고 중앙 생존기간은 7 9개월로 대증요법으로 치료할 때의 2 개월보다 생존기간의 연장은 있었으나 장기 생존자는 많 지 않아 3년 후 무병 생존자는 3 5\%에 불과하다 $(8,9)$. EP 복합항암화학요법은 $\mathrm{CAV}$ 요법에 실패한 한자에서 40 $50 \%$ 의 관해율을 나타내어 관심이 높아져 1차적 치료로 이 용되었다 $(5,10)$. 치료효과를 높이기 위한 방법으로 교대요 법이 시행되었으나 CAV/EP 교대요법과 CAV또는 EP 단독 요법을 비교한 3상 연구에서는 교대요법군이 특별히 더 우 수하지는 않았다 $(11,12)$. 이는 국내에서 서 등(13)이 전신성 병기의 소세포폐암에 대한 $\mathrm{EP}$ 와 $\mathrm{CAV} / \mathrm{EP}$ 교대요법의 비교 연구에서도 유사한 결과를 얻었다. 본 연구에서는 ifosfamide, carboplatin, epirubicin (ICE)이 사용되었다. Carboplatin은 cisplatin 유도체로서 소세포폐암에서 $60 \%$ 의 반응률 을 보이고 cisplatin 보다 신독성, 신경독성, 그리고 위장관 독성이 적다는 장점이 있는 반면 용량제한 독성으로 골수 억제 특히 혈소판 감소가 발생된다 $(14,15)$. Ifosfamide 또한 단일제제로서 높은 반응률을 보이며 cyclophosphamide보다 골수억제가 적은 장점이 있다. Le chevalier 등(16)은 이전에 화학요법을 받지 않았던 환자 30명을 대상으로 carboplatin, ifosfamide 복합항암화학요법을 시행하여 $63 \%$ 의 반응률과, 8 개월의 중앙 생존기간, 3 개월의 관해 유지기간과 혈액학 적 독성으로는 골수억제가 3도/4도의 경우 각각 3명/4명에 서 발생함을 보고하였다. 또한 ifosfamide와 carboplatin에 반 응을 하지 않은 환자에 대하여 doxorubicin과 etoposide를 사 용하였을 때 11 명 중 4 명에서 반응을 보여 doxorubicin과 etoposide와는 cross-resistance가 없음을 보고하였다. Postmus
등도(17) 소세포폐암에서 흔히 사용되는 cyclophosphamide, doxorubicin, etoposide (CDE)와 ifosfamide, carboplatin (IMP) 의 효과를 비교하였을 때 반응률은 각각 $83 \%, 77 \%$ 이었고 중앙 생존기간은 49 주, 37 주를 보여 $\mathrm{CDE}$ 와 $\mathrm{IMP}$ 사이에 의 미 있는 차이가 없어 소세포폐암에서 IMP의 사용의 가능성 을 보고하였다. Carboplatin을 근간으로 하는 다른 방법으로 는 주로 etoposide와 carboplatin에 한 가지 또는 두 가지의 약제를 추가하는 방법을 사용하고 있으나 결과는 모두 유 사하였다 $(18,19)$ IMP 화학요법의 주요 독성은 혈액학적 독 성으로 3 도 내지 4 도의 백혈구 감소와 혈소판 감소가 약 $50 \%$ 에서 발생하였다. 이러한 독성을 감소시키는 방법으로 carboplatin의 용량을 신장기능에 따라 개별화시키는 방법 (20), 성자인자를 사용하는 방법이 사용되었다(21). 본 연구 에서 반응률 및 생존기간을 증진시키고 독성을 감소시키려 는 목적으로 ifosfamide, carboplatin에 cross-resistance가 없다 고 알려진 doxorubicin 대신에 같은 anthracyclin의 일종인 epirubicin (ICE)을 추가하여 3제 복합화학요법을 시행하였 고, 한편으로는 혈액학적 독성을 감소시키기 위한 방법으 로 carboplatin의 용량을 Calvert formula를 이용하여 개별화 하였다. 전신성 병기의 소세포폐암에서 $\mathrm{ICE}$ 의 반응률은 $65 \%$ (13/20)였고 관해 유지기간의 중앙값은 15.4주(범위 4.3 47.9주), 생존기간은 중앙값이 34 주(범위 8.7 62.7주), 질병 의 진행까지의 기간은 중앙값이 18.3 주(범위 6.3 54.4주)였 다. 이는 소세포폐암에서 많이 사용되고 있는 $\mathrm{CAV}$ 또는 $\mathrm{EP}$ 와 유사한 결과를 보였고, IMP와도 유사한 결과를 보여 기 존의 화학요법의 결과와 비교하여 볼 때 반응률 및 생존기 간의 증가는 없어 보였다. 본 연구의 독성의 평가 부분에서 비혈액학적 독성은 대부분 1 도 내지 2 도로서 수용할 수 있 는 정도였다. 혈액학적 독성으로는 백혈구 감소와 혈소판 감소가 4 5\%로 다른 연구자보다는 적게 나왔고 이는 독성 을 감소시키려는 방법과 혈액검사를 다음 항암제를 투여 하기 직전에 검사한 결과를 토대로 하였기 때문으로 생각 된다.

\section{결 론}

ICE 복합항암화학요법은 전신성 병기의 소세포폐암에서 효과적이고 독성도 수용할 정도로 비교적 안전하게 사용 될 수 있었다.

\section{REFERENCES}

1. Boring CC, Squires TS, Tong T. Cancer statistics, 1993. CA Cancer J Clin 1993;43:7-26.

2. Ihde DC. Chemotherapy of lung cancer. N Engl J Med 
1992;327:1434-1441.

3. Bunn PA Jr, Lichter AS, Makuch RW, Cohen MH, Veach SR, Matthews MJ, Anderson AJ, Edison M, Glatstein E, Minna JD, et al. Chemotherapy alone or chemotherapy with chest radiation therapy in limited stage small cell lung cancer. A prospective, randomized trial. Ann Intern Med 1987;655-662.

4. Souhami RL, Geddes DM, Spiro SG, Harper PG, Tobias JS, Mantell BS, Fearon F, Bradbury I. Radiotherapy in small cell cancer of the lung treated with combination chemotherapy: a controlled trial. Br Med J (Clin Res Ed) 1984;288:1643-1646.

5. Evans WK, Shepherd FA, Feld R, Osoba D, Dang P, Deboer G. VP-16 and cisplatin as first-line therapy for small-cell lung cancer. J Clin Oncol 1985;3:1471-1477.

6. Murren J, Glatstein E, Pass HI. Small cell lung cancer, in: DeVita VT Jr, Hellman S, Rosenberg SA, eds. Cancer: Principles and Practice of Oncology. 6th ed. Philadelphia: Lippincott-Raven, 2001; 983-1018.

7. Oldham RK, Greco FA. Small-cell lung cancer. A curable disease. Cancer Chemother Pharmacol 1980;4:173-177.

8. Feld R, Pringle JF, Evans WK, Keen CW, Quirt IC, Curtis JE, Baker MA, Yeoh JL, Deboer G, Brown TC. Combined modality treatment of small cell carcinoma of the lung. Arch Intern Med 1981;141:469-473.

9. Feld R, Evans WK, DeBoer G, Quirt IC, Shepherd FA, Yeoh JL, Pringle JF, Payne DG, Herman JG, Chamberlain D, et al. Combined modality induction therapy without maintenance chemotherapy for small cell carcinoma of the lung. J Clin Oncol 1984;2:294-304.

10. Evans WK, Osoba D, Feld R, Shepherd FA, Bazos MJ, DeBoer G. Etoposide (VP-16) and cisplatin: an effective treatment for relapse in small-cell lung cancer. J Clin Oncol 1985;3:65-71.

11. Goodman GE, Crowley JJ, Blasko JC, Livingston RB, Beck TM, Demattia MD, Bukowski RM. Treatment of limited small-cell lung cancer with etoposide and cisplatin alternating with vincristine, doxorubicin, and cyclophosphamide versus concurrent etoposide, vincristine, doxorubicin, and cyclophosphamide and chest radiotherapy: a Southwest Oncology Group Study. J Clin Oncol 1990;8:39-47.

12. Feld R, Evans WK, Coy P, Hodson I, MacDonald AS, Osoba D, Payne D, Shelley W, Pater JL. Canadian multicenter randomized trial comparing sequential and alternating administration of two non-cross-resistant chemotherapy combinations in patients with limited small-cell carcinoma of the lung. J Clin Oncol 1987;5:1401-1409.
13. Suh CI, Park YS, Chung KS, Heo DS, Bang YJ, Kim NK. A randomized comparison of EP sequential chemotherapy versus EP/CAV alternating chemotherapy for extensive-stage small-cell lung cancer. J Korean Cancer Assoc 1994;26:786795.

14. Smith IE, Harland SJ, Robinson BA, Evans BD, Goodhart LC, Calvert AH, Yarnold J, Glees JP, Baker J, Ford HT. Carboplatin: a very active new cisplatin analog in the treatment of small cell lung cancer. Cancer Treat Rep 1985;69:43-46.

15. Calvert AH, Harland SJ, Newell DR, Siddik ZH, Jones AC, McElwain TJ, Raju S, Wiltshaw E, Smith IE, Baker JM, Peckham MJ, Harrap KR. Early clinical studies with cisdiammine-1,1-cyclobutane dicarboxylate platinum II. Cancer Chemother Pharmacol 1982;9:140-147.

16. Le Chevalier T, Thomas F, Subirana R, Baldeyrou P, Ruffie P, Arriagada R, Chazard M, Tursz T. A phase II study of the combination of carboplatin and ifosfamide in previously untreated metastatic small cell lung carcinoma. Cancer 1991; 67:2980-2983.

17. Postmus PE, Splinter TA, Palmen FM, Carney DN, Festen J, Burghouts JT, Vendrik C, Roozendaal K, Planting AS, Quoix $\mathrm{E}$, et al. Comparison of two carboplatin-containing regimens with standard chemotherapy for small cell lung cancer in a randomised phase II study. The EORTC Lung Cancer Cooperative group. Eur J Cancer 1992;28:96-100.

18. Smith IE, Perren TJ, Ashley SA, Woodiwiss J, Forgeson GV, Yarnold JR, Ford HT. Carboplatin, etoposide, and ifosfamide as intensive chemotherapy for small-cell lung cancer. J Clin Oncol 1990;8:899-905.

19. Thatcher N, Lind M, Stout R, Payne C, Carroll KB, Campbell C, Moussalli H. Carboplatin, ifosfamide and etoposide with mid-course vincristine and thoracic radiotherapy for 'limited' stage small cell carcinoma of the bronchus. Br J Cancer 1989; 60:98-101.

20. Calvert AH, Newell DR, Gumbrell LA, O'Reilly S, Burnell M, Boxall FE, Siddik ZH, Judson IR, Gore ME, Wiltshaw E. Carboplatin dosage: prospective evaluation of a simple formula based on renal function. J Clin Oncol 1989;7:1748-1756.

21. de Vries EG, Biesma B, Willemse PH, Mulder NH, Stern AC, Aalders JG, Vellenga E. A double-blind placebo-controlled study with granulocyte-macrophage colony-stimulating factor during chemotherapy for ovarian carcinoma. Cancer Res 1991;51:116-122. 